Tạp chi Khoa học và Công nghệ, Số 44, 2020

\title{
THỬ NGHIỆM SẢN XUẤT VÀ BƯớC ĐẦU ỨNG DỤNG BỘT ĐẠM TÙ TRÙN QUẾ (Perionyx excavatus) LÊN ĐÀN HEO CON LAI (Yourshire và Landrace) SAU CAI SŨ்
}

\author{
PHẠM TÂN VIẸT ${ }^{1}$, NGUYỄN NGỌC HUY ${ }^{2}$, HỨA HUỲNH MINH THẢO ${ }^{1}$, BÙI THỊ LUYẾN ${ }^{3}$, \\ NGUYỄN THANH HẢI ${ }^{3}$, NGUYỄN NGỌC Ẩ ${ }^{1}$, NGUYỄN THI DIẸU HẠNH ${ }^{*}$ \\ ${ }^{I}$ Viện Công nghệ Sinh học và Thưc phẩm, Trương Đại học Công nghiệp Thành phố Hồ Chí Minh \\ ${ }^{2}$ Chi cuc an toàn vệ sinh thưc phẩm An Giang \\ ${ }^{3}$ Trường Đại học Khoa học Tự nhiến Thành phố Hồ Chỉ Minh \\ nguyenthidieuhanh@iuh.edu.vn
}

Tóm tắt. Trùn quế (Perionyx excavatus) là loài sinh vật phổ biến và có ích trong việc tham gia cải tạo và cung cấp dưỡng chất cho đất nông nghiệp. Bên cạnh đó, hàm lượng đạm cao trong thịt trùn quế cũng là nguồn dưỡng chất dồi dào cho ngành chăn nuôi. Chúng tôi đã tiến hành thuỷ phân thịt trùn quế bằng hệ thống lên men bán tự động trong 18 giờ ở nhiệt độ $40^{\circ} \mathrm{C}$, tốc độ khuấy 130 vòng/phút, $\mathrm{pH} 6,5$. Hỗn hợp lên men được bổ sung $5 \%$ rỉ đường, $1 \%$ enzyme protease SEB-Neutral $\mathrm{PL}, 5 \mathrm{mM} \mathrm{Ca}^{2+}$ và $40 \%$ thị trùn quế. Dịch thuỷ phân được sấy phun với $20 \%$ maltodextrin M100 để tạo bột đạm hoà tan nhằm dể dàng bảo quản, vận chuyển và bổ sung cho chăn nuôi. Đàn heo sử dụng $2 \%$ bột đạm từ thịt trùn quế trong khẩu phần ăn có tốc độ tăng trưởng tốt nhất. Các đàn heo sử dụng bột đạm từ thịt trùn quế đều có sức khoẻ và hoạt động sinh lý ổn định. Nghiên cứu này sẽ tiếp tục được thực hiện trên nhiều đối tượng khác để nhằm thương mại hoá sản phẩm bột đạm từ thịt trùn quế.

Từ khóa. Perionyx excavatus, heo con sau cai sữa, enzyme protease SEB-Neutral PL, sấy phun.

\section{EFFECT OF PROCESSED PROTEIN RICH POWDER FROM Perionyx excavatus ON YOURSHIRE AND LANDRACE WEANER PHYSIOLOGY: PRELIMINARY PRODUCTION AND APPLICATION}

\begin{abstract}
Perionyx excavates, a common earthworm species plays an important role in improving soil structure and fertility. In addition, the high protein content of earthworm is also a valuable source of nutrients for the livestock industry. In this study, earthworm hydrolysis was prepared in a homemade semi-automatic fermentation system. The preliminary optimal fermentation conditions were found to be 18 hours at $40^{\circ} \mathrm{C}, 130$ revolutions per minute, $\mathrm{pH} 6.5$, and in the presence of $5 \%$ molasses, $1 \%$ SEBNeutral PL protease, $5 \mathrm{mM} \mathrm{Ca}^{+}$for $40 \%$ earthworm meat as starting raw material. Hydrolysate solution was mixed with $20 \%$ maltodextrin M100 and subjected to spray dried to create soluble protein rich powder for easy storage, transport and used as breeding supplement. We showed that weaners piglets supplemented with $2 \%$ protein rich powder displayed the best growth with good health and stable physiological activities. Undergoing farm-scale studies have been carried out on many other domestic animals in order to commercialize this Perionyx excavatus processed protein rich powder product.
\end{abstract}

Keywords. Perionyx excavatus, weaner physiology, processed protein rich powder, enhanced production.

\section{GIỚI THIÊU}

Theo số liệu của tổng cục thống kê Viêt Nam, tổng đàn heo đang ngày một gia tăng. Do đó, nhu cầu về thức ăn cho đàn heo cũng sẽ tăng mạnh. Trong đó, thức ăn cho heo con vừa tách mẹ là hết sức bức thiết vì ở độ tuổi này nhu cầu dinh dưỡng của chúng rất khác biệt. Ở lứa tuổi này, heo con cần một khẩu phần ăn đầy đủ năng lượng với hàm lượng đạm cao và đáp ứng đầy đủ các thành phần amino acid nhất là các amino acid thiết yếu. Các amino acid này đảm bảo cân đối dinh dưỡng cho heo con mà còn hỗ trợ miễn dịch [1]. Theo truyền thống, amino acid được chia làm 2 nhóm thiết yếu và không thiết yếu trong cơ thể động vật. Động vật phải bổ sung các amino acid thiết yếu cho cơ thể của mình để phục vụ việc sinh tổng 
hợp các protein cho cơ thể vì bản thân chúng không thể tự tổng hợp các amino acid này [2]. Tuy nhiên, ngày càng có nhiều bằng chứng cho thấy heo con không thể tự tổng hợp đủ lượng amino acid không thiết yếu cho sự sinh trưởng, phát triển và thành thục của chúng [3].

Amino acid đóng vai trò quan trọng trong việc duy trì các chức năng sinh lý của cơ thể vật nuôi [4]. Gần đây người ta còn nhận thấy amino acid còn đóng vai trò điều hoà các con đường chuyển hoá đáp ứng cho sự sống, sinh trưởng và phát triển ở heo con [5]. Các amino acid đóng vai trò điều hoà nói trên còn được gọi là các amino acid chức năng, bao gồm arginine, cysteine, glutamine, glutamate, glycine, leucine, proline và tryptophan [6].

Trong khẩu phần của heo con, protein là chất dinh dưỡng đắt tiền nhất. Tuy nhiên, việc chuyển hoá và hấp thu protein lại là quá trình phức tạp. Hầu hết các amino acid trong khẩu phần ăn của heo con sẽ được sử dụng để tổng hợp protein ngoại trừ glutamate, glutamine và aspartate sẽ tiếp tục bị phân giải trong ruột non [7]. Trong khẩu phần ăn của heo con không thể thiếu arginine, histidine, isoleucine, leucine, lysine, methionine, phenylalanine, threonine, tryptophan, và valine. Heo con không thể tổng hợp các amino acid này ngoại trừ arginine, vì thế người nuôi phải cung cấp đầy đủ các amino acid này trong khẩu phần ăn của chúng. Cysteine, glutamate, glutamine, glycine, proline và tyrosine hiện nay đang được xem là các amino acid thiết yếu có điều kiện vì chúng được tổng hợp không đầy đủ ở một số giai đoạn sống nhất định của heo (ví dụ như giai đoạn sơ sinh) hoặc một số điều kiện nuôi dưỡng nhất định (cho heo con đang cai sữa ăn nhiều bắp và đậu nành) [8].

Trùn đất là nhóm sinh vật có vai trò rất quan trọng trong nông nghiệp. Chúng tham gia phân giải các thành phần hữu cơ trong đất và góp phần cải tạo cấu trúc đất trồng [9]. Ngoài công dụng cải tạo đất, xử lý xác bã hữu cơ, trùn đất còn được sử dụng rộng rãi trong kỹ nghệ chăn nuôi gia súc, gia cầm [10]. Theo phân tích của Edward và Lofty, protein chiếm $65 \%$, chất béo chiếm $14 \%$, carbonhydrate chiếm $14 \%$ trọng lượng thịt trùn quế khô [11].

Thịt trùn giàu lysine và methionine. Hàm lượng arginine, lysine, glutamic acid và leucine cao hơn hẳn trong bột cá. Bên cạnh đó, hàm lượng tryptophan trong thịt trùn cao gấp bốn lần so với trong bột máu và cao gấp bảy lần so với trong gan bò [12]. Các loại protein trong thịt trùn là nguồn dưỡng chẩt dễ dàng được hấp thu bởi vật nuôi và hiện tại đang được sử dụng làm nguồn dinh dưỡng bổ sung cho chăn nuôi ở nhiều quốc gia như Mỹ, Canada và Nhật [13]. Ngoài ra, thịt trùn đã được chứng minh là có tác động tích cực lên sự tăng trưởng của nhiều loài cá nuôi [14].

Thịt trùn sau khi được thuỷ phân bởi các enzyme sẽ tạo ra một dung dịch peptide và các amino acid tự do có phân tử lượng thấp, dung dịch này sẽ dễ dàng được hấp thu và thể hiện chức năng bởi gia súc và gia cầm, việc này tạo điều kiện thuận lợi cho khả năng cồng nghiệp hoá các loại thức ăn cho chăn nuôi với nguyên liệu là trùn đất thuỷ phân [15]. Quá trình thuỷ phân thịt trùn đất có thể được thực hiện bằng cách sử dụng enzyme hoặc bằng các quá trình hoá học [16]. Tuy nhiên, Maldonado và cộng sự đã cho thấy việc sử dụng enzyme có nhiều ưu thế hơn [17]. Sản phẩm thuỷ phân bởi enzyme có hiệu suất cao hơn, hạn chế các sản phẩm phụ và bảo tồn được giá trị dinh dưỡng của sản phẩm sau thuỷ phân [18].

Đã có rất nhiều các nghiên cứu ứng dụng enzyme vào công nghiệp sản xuất thức ăn cho vật nuôi. Việc thuỷ phân protein bằng enzyme đã được tiến hành trên nhiều loại như protein của cá, gà và heo đều đem lại hiệu quả cao trong chăn nuôi [19]. Tuy nhiên đến thời điểm hiện tại vẫn còn khá ít các nghiên cứu về việc sử dụng enzyme để thuỷ phân thịt trùn đất làm nguồn thức ăn bổ sung cho gia súc, gia cầm [20].

Trong nghiên cứu này, chúng tôi đã tiến hành thuỷ phân thịt trùn, chuyển dịch thuỷ phân thành dạng bột khô hoà tan nhằm kéo dài thời gian bảo quản, thuận tiện trong việc vận chuyển và sử dụng. Chúng tôi bước đầu đánh giá hiệu quả sử dụng bột dinh dưỡng này trên đàn heo con sau cai sữa.

\section{VẬT LIỆU \& PHƯƠNG PHÁP NGHIÊN CÚU}

\subsection{Vật liệu nghiên cứu}

Trùn quế được sử dụng để lên men tạo dịch và bột dinh dưỡng là giống Perionyx excavatus được cung cấp bởi công ty Cổ phần Trùn quế Củ Chi, thành phố Hồ Chí Minh.

Nghiên cứu được thực hiện trên giống heo lai Yourshire và Landrace tại trại chăn nuôi Vĩnh Khánh thuộc Công ty Cổ phần xuất nhập khẩu nông sản thực phẩm An Giang, tỉnh Án Giang.

Protease SEB-Neutral PL lỏng xuất xứ Ân Độ được công ty Hưng Thịnh Việt Nam cung cấp. 


\section{2. Đánh giá hiệu suất thuỷ phân}

Trùn quế từ công ty được làm sạch nhanh trong nước, làm ráo và phân thành từng lô với khối lượng bằng nhau $(20 \mathrm{~g})$. Các túi đựng trùn quế được cấp đông để thực hiện các thí nghiệm trong kế hoạch.

Các túi trùn quế được lên men theo từng nghiệm thức nhất định. Thành phần cơ bản của mỗi nghiệm thức là trùn quế, enzyme protease, rỉ đường và nước. Thể tích sau cùng của mỗi phản ứng là $50 \mathrm{ml}$. Hỗn hợp phản ứng được cho vào cốc thuỷ tinh, đặt trên máy khuấy từ gia nhiệt 10 vị trí (RSM-03-10KH, Phoenix Instrument-Đức). Nhiệt độ lên men được duy trì trong khoảng $40^{\circ} \mathrm{C}$ với tốc độ khuấy 130 vòng/phút [21].

Hiệu suất thuỷ phân được tính dựa trên sự còn lại của cơ chất sau quá trình thuỷ phân. Kết thúc quá trình thuỷ phân, $1 \mathrm{ml}$ dịch được cho vào microtube, ly tâm 14.000 vòng ở $4^{\circ} \mathrm{C}$ trong 10 phút. Phần dịch nổi được tách riêng, xác định khối lượng phần cặn lắng [22].

\subsection{Xác định các yếu tố ảnh hưởng đến quá trình thuỷ phân thịt trùn quế}

Để có được công thức lên men tốt, thịt trùn quế được xử lý và lên men với nhiều công thức khác nhau. Chúng tôi thử nghiệm để nguyên thịt trùn và xay thịt trùn, lên men tĩnh hoặc có khuấy trộn. Chúng tôi thay đổi nồng độ rỉ đường từ $0-40 \%$. Chúng tôi khảo sát nồng độ enzyme bổ sung từ $0-4 \%$ và chúng tôi khảo sát để tìm kim loại hỗ trợ cho hoạt động của enzyme protease SEB-Neutral PL như $\mathrm{Zn}^{2+}, \mathrm{Al}^{3+}$, $\mathrm{Fe}^{2+}, \mathrm{Ca}^{2+}, \mathrm{Mg}^{2+}$ và $\mathrm{Mn}^{2+}$. Tất cả các thí nghiệm được thực hiện ở khoảng $40^{\circ} \mathrm{C}$ và $\mathrm{pH} 6,5$ như khuyến cáo của nhà sản xuất enzyme.

\subsection{Phương pháp sấy phun sản xuất bột đạm từ thịt trùn quế}

Dịch thuỷ phân được bô sung 20\% Maltodextrin (M100 - được cung cấp bởi công ty Brenntag) và được sấy phun trong hệ thống sấy phun công nghiệp của công ty Cổ phần $\mathrm{BV}$ pharma (hình 3.b). Hệ thống sấy phun được vận hành với tốc độ cấp dịch $100 \mathrm{ml} /$ phút, nhiệt độ buồng sấy $135^{\circ} \mathrm{C}$, nhiệt độ thu hồi $85^{\circ} \mathrm{C}$.

\subsection{Bố trí thực nghiệm trên đàn heo con sau cai sữa}

Đàn heo con sau cai sữa (26 ngày tuổi) không biệt giới tính, có trọng lượng trung bình $7,0 \pm 1,0 \mathrm{~kg}$ được chia thành 4 lô. Mỗi lô 12 cá thể được chia thành 2 ngăn. Mỗi nghiệm thức lặp lại 3 lần.

Bột đạm bổ sung được phối trộn trực tiếp vào cám và cung cấp cho đàn heo theo các nghiệm thức:

Lô A: lô đối chứng, chỉ cho ăn thức ăn của trại.

Lô B: bổ sung $10 \mathrm{~g}$ bột đạm $/ \mathrm{kg}$ thức ăn của trại.

Lô C: bổ sung $20 \mathrm{~g}$ bột đạm $/ \mathrm{kg}$ thức ăn của trại.

Lô D: bổ sung $30 \mathrm{~g}$ bột đạm $/ \mathrm{kg}$ thức ăn của trại.

Thí nghiệm được tiến hành trong 4 tuần, cho đến khi đàn heo đủ tuổi và trọng lượng chuyển qua giai đoạn nuôi thịt. Kết thúc 4 tuần thí nghiệm, hàm lượng bạch cầu trong máu heo được ghi nhận để sơ bộ đánh giá sức khoẻ của đàn heo.

\subsection{Xác định trọng lượng heo, tỷ lệ tiêu chảy và lượng bạch cầu trong máu}

Đàn heo được cho ăn 4 lần/ngày. Mỗi lần thức ăn được đổ thành nhiều đợt vào máng. Lượng thức ăn được thay đổi theo từng ngày phù hợp với nhu cầu thực tế của đàn heo. Bột dinh dưỡng bổ sung được cấp vào ngay lần đổ đầu tiên của mỗi lần cho ăn để đảm bảo đàn heo ăn hết chất bổ sung này.

Trọng lượng heo được xác định 1 tuần/lần bằng cách cân tổng đàn heo trong từng 2 ngăn (6 cá thể).

Số lượt tiêu chảy được ghi nhận theo từng máng ăn ( 2 ngăn chuồng -6 cá thể) trong suốt quá trình nuôi và được chia thành 4 tuần.

Sau 4 tuần nuôi, tiến hành thu mẫu máu của các cá thể heo để xác định lượng bạch cầu tổng số bằng phương pháp đếm trên buồng đếm bạch cầu.

\subsection{Phương pháp thống kề và xử lý số liệu}

Giá trị kết quả của các thí nghiệm là trung bình của 3 lần lặp lại. Số liệu được tính toán, vẽ biểu đồ trên Microsoft Excel 2013 và được xử lý thống kê bằng phương pháp ANOVA bằng phần mềm GraphPad Prism 8.

\section{KẾT QUẢ VÀ THẢO LUẬn}

3.1. Hiệu suất thuỷ phân thịt trùn quế dưới ảnh hưởng của các yếu tố

Thịt trùn quế được thuỷ phân trong dung dịch cơ bản có bổ sung enzyme, rỉ đường và nước. Kết quả khảo sát cho thấy, khi thịt trùn được xay nhuyễn và được lên men trong điều kiện khuấy đảo cho hiệu suất cao hơn các nghiệm thức khác. Sau 18 giờ lên men có khuấy đảo hiệu suất thuỷ phân cao hơn sự men tĩnh với 
trùn nguyên con gấp 3 lần (hình 1.a). Điều này phù hợp với hoạt động của enzyme. Hoạt tính của enzyme sẽ tốt hơn khi tiếp xúc nhiều và trên bề mặt lớn của khối cơ chất. Việc khuấy đảo còn giúp nhiệt độ của phản ứng đồng đều, hiệu suất phản ứng ổn định [23].

Hiệu suất thuỷ phân thịt trùn quế cao nhất sau 18 giờ lên men không có sự khác biệt khi bổ sung $1 \%$ hay $5 \%$ rỉ đường. Cả 2 nghiệm thức này đều cho hiệu suất thuỷ phân trên $80 \%$ (hình $1 . b$ ). Tuy nhiên, ở nghiệm thức chỉ sử dụng $1 \%$ rỉ đường, sản phẩm lên men có mùi thối, dịch lên men đục, có biểu hiện của sự nhiễm khuẩn nghiêm trọng. Ở nghiệm thức bổ sung $5 \%$ rỉ đường, sản phẩm lên men trong có màu nâu cánh gián đẹp và có mùi thơm. Với việc bổ sung $40 \%$ rỉ đường, hiệu suất thuỷ phân giảm mạnh. Như vậy, việc thuỷ phân thịt trùn quế có sự tham gia của hệ vi sinh vật trong tự nhiên. Tuy nhiên, các vi sinh vật này ngoài việc thuỷ phân protein từ thịt trùn quế thành dịch đạm còn tạo ra nhiều sản phẩm phụ có thể gây mất cảm quan thậm chí gây độc trên sản phẩm lên men. Nồng độ rỉ đường tăng cao giúp ức chế hoạt động của hệ vi sinh vật phân giải protein nhưng nồng độ cao này cũng ức chế hoạt động của enzyme protease bổ sung. Điều này phù hợp với nghiên cứu của Wang và cộng sự (2019) khi khảo sát ảnh hưởng của mật rỉ đường trên hoạt động của các chủng vi sinh vật phân giải carbonhydrate [24].

(a)

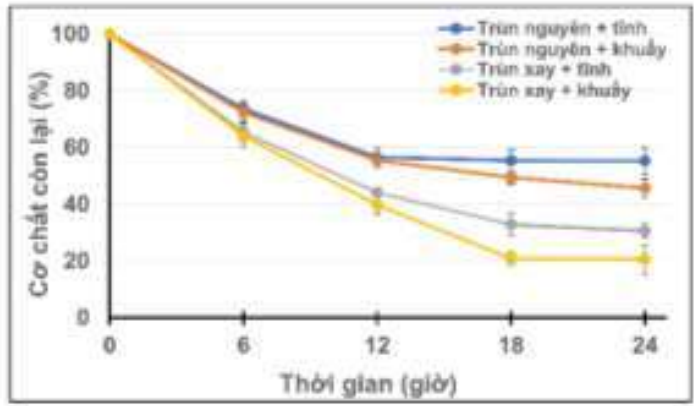

(b)

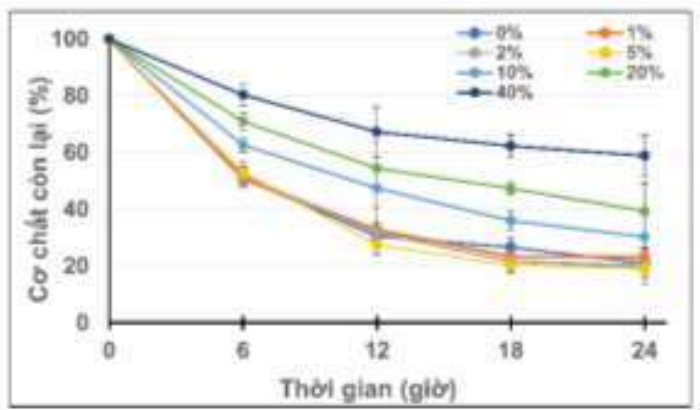

Hình 1. Hiệu suất thuỷ phân thịt trùn quế khi xay nhuyễn có khuấy trộn (a) và khi thay đổi nồng độ rỉ đường trong phản ứng $(b)$.

Nồng độ enzyme bổ sung vào quá trình lên men là một yếu tố quan trọng trong sản xuất, yếu tố này quyết định mạnh đến tốc độ lên men và giá thành sản phẩm [15]. Từ thực nghiệm, chúng tôi nhận thấy với $4 \%$ enzyme bổ sung, tốc độ phản ứng được đẩy mạnh ngay từ đầu quá trình lên men (hình $2 . a)$. Tuy nhiên, sau 18 giờ lên men, hiệu suất thuỷ phân của các nghiệm thức bổ sung $1 \%, 2 \%$ và $4 \%$ không còn khác biệt. chất lượng sản phẩm thuỷ phân thịt trùn quế như nhau trong các nghiệm thức này. Chính vì vậy, chúng tôi sẽ bổ sung $1 \%$ enzyme protease vào sản xuất quy mô lớn nhằm tiết kiệm chi phí. Nirmal và cộng sự (2014) cũng bổ sung $1 \%$ protease trong các nghiên cứu của nhóm [25]. Năm 2016, Berg và công sự cũng đã sử dụng tỷ lệ bổ sung này khi nghiên cứu các công thức thuỷ phân protein trong thực phẩm [26].

Protease là một nhóm enzyme lớn thuộc lớp 3 - enzyme thuỷ phân - nhóm enzyme này hoạt động trong nhiều điều kiện phản ứng tuỳ thuộc vào cấu trúc không gian đặc biệt là cấu trúc trung tâm hoạt động của enzyme này [27]. Tuỳ vào từng loại protease với hoạt tính riểng đặc hiệu mà chúng cần một hoặc nhiều loại cofactor hỗ trợ cho hoạt động thuỷ phân protein [28]. Trong phạm vi nghiên cứu này, chúng tôi không có điều kiện xác định cấu trúc trung tâm hoạt động của enzyme protease SEB-Neutral PL. Để xác định cofactor phù hợp của enzyme này chúng tôi đã tiển hành kiểm tra tác động của một số ion kim loại như $\mathrm{Zn}^{2+}, \mathrm{Al}^{3+}, \mathrm{Fe}^{2+}, \mathrm{Ca}^{2+}, \mathrm{Mg}^{2+}$ và $\mathrm{Mn}^{2+}$ với nồng độ bổ sung $5 \mathrm{mM}$. Ngay từ đầu thực nghiệm, ion $\mathrm{Ca}^{2+}$ và $\mathrm{Mg}^{2+}$ đã cho thấy hiệu quả rõ rệt lên hoạt tính thuỷ phân thịt trùn quế của protease này (hình $2 . b$ ). Trong đó, các muối calcium khá phổ biến và có giá thành thấp ở Việt Nam. Ngoài ra, calcium cũng là một thành phần dinh dưỡng không thể thiếu cho vật nuôi trong việc hình thành xương, tham gia dẫn truyền thần kinh [29]. Chính vì vậy, chúng tôi chọn calcium làm nguồn cofactor cho quá trình lên men quy mô lớn. 
(a)

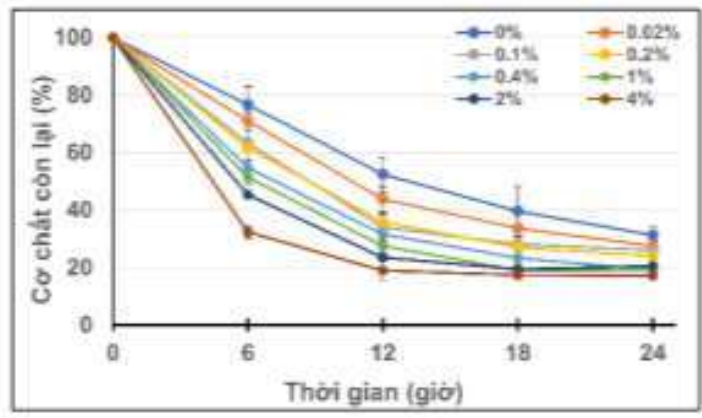

(b)

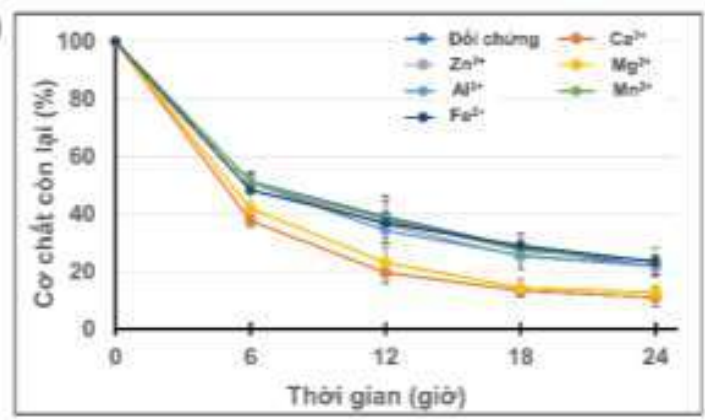

Hình 2. Hiệu suất thuỷ phân thịt trùn quế khi thay đổi nồng độ enzyme protease bổ sung (a) và khi thay đổi cofactor cho hoạt động của protease (b).

\subsection{Lên men thịt trùn quế với enzyme protease quy mô lớn và thử nghiệm sản xuất bột dinh dưỡng}

Với các thông số khảo sát thực nghiệm, chúng tôi tiến hành các mẻ lên men quy mô lớn trên thiết bị lên men bán tự động được thiết kế đảm bảo ổn định các thông số cơ bản của quá trình lên men (hình 3.a).

(a)

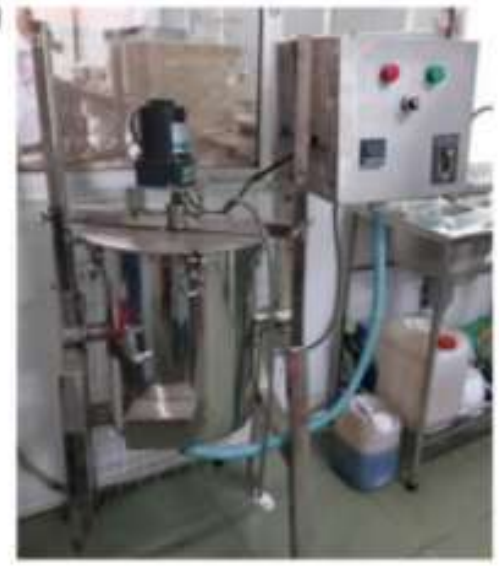

(b)

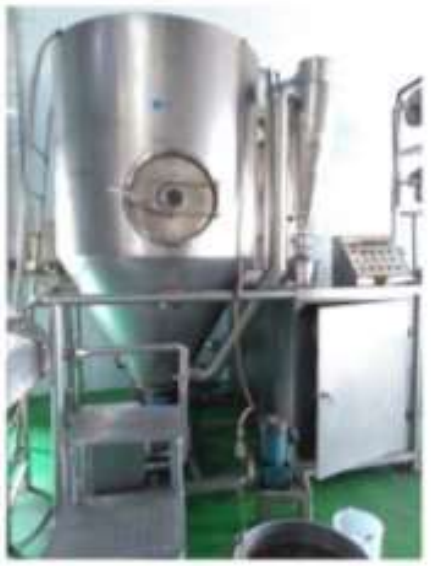

(c)

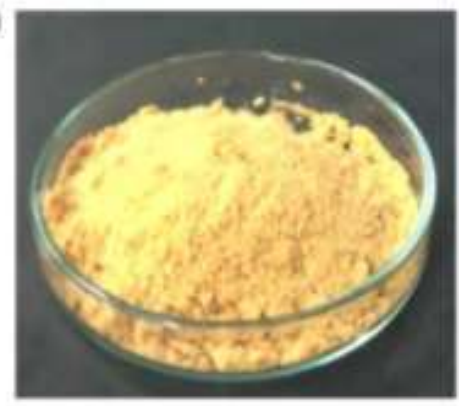

Hình 3. Thiết bị lên men bán tự động quy mô 15 lít/mẻ (a) và hệ thống sấy phun quy mô 5lít/giờ (b) và sản phẩm bột dinh dưỡng thành phẩm $(\mathrm{c})$.

Thành phần của mỗi mẻ lên men bao gồm: $40 \%$ thịt trùn quế, $1 \%$ enzyme protease, $5 \%$ rỉ đường, $5 \mathrm{mM} \mathrm{Ca}{ }^{2+}$. Quá trình lên men tiến hành trong 18 giờ, nhiệt độ ổn định khoảng $40^{\circ} \mathrm{C}, \mathrm{pH}$ dao động $6,5-7,0$ và tốc độ cánh khuấy 130 vòng/phút. Với thiết bị lên men bán tự động được thiết kế hoàn toàn bằng inox 304 sử dụng cho công nghệ thực phẩm, hiệu suất thuỷ phân tăng lên đáng kể so với kết quả thí nghiệm. Sau 18 giờ lên men, toàn bộ dịch lên men được lọc qua màng lọc chuyên dụng đảm bảo kích thước hạt phù hợp để nạp vào hệ thống sấy phun. Hiệu suất thuỷ phân đạt hơn $90 \%$.

Dịch thuỷ phân được bổ sung 20\% Maltodextrin (M100 - được cung cấp bởi công ty Brenntag) và được sấy phun trong hệ thống sấy phun công nghiệp của công ty Cổ phần BV pharma (hình 3.b). Các thông số sấy được điều chỉnh phù hợp với thông số máy, hiệu suất thu hồi bột sấy và cảm quan của sản phẩm sấy (hình 3.c). Bột sấy (bột đạm từ thịt trùn quế) được tiến hành phân tích hàm lượng và thành phần amino acid tại Trung tâm Sắc ký Hải Đăng.

So sánh kết quả phân tích dịch thuỷ phân thịt trùn quế và bột đạm từ thịt trùn quế của chúng tôi với dịch thuỷ phân thịt trùn quế trên thị trường - NUTRI-T, cung cấp bởi công ty TNHH Thương mại Đầu tư Renabeco, chúng tôi thấy rằng hàm lượng amino acid tổng trong mẫu của chúng tôi cao hơn gần 5 lần và thành phần amino acid thiết yếu cho heo cũng cao hơn (kết quả phân tích được bổ sung trong phụ lục). Đặc biệt hàm lượng threonin cao khoảng gấp 8 lần. Theo nghiên cứu của Nguyễn Thị Mỹ Hương và cộng 
sự năm 2014, tiến hành thủy phân đầu và xương cá chẽm bằng enzyme thương mại Flavourzyme với tỉ lệ 0,5\% nguyên liệu sau 6 giờ thu được hàm lượng amino acid tổng: $37,7 \pm 0,28 \mathrm{~g} / 100 \mathrm{~g}$ bột protein, cao hơn gấp 3 lần so với chế phẩm bột đạm của chúng tôi [30]. Liaset và cộng sự (2003) thực hiện thủy phân xương cá hồi với enzyme thương mại Protamex ${ }^{\mathrm{TM}}$ của Novozymes với tỉ lẹ̣ $0,12 \%$ so với cơ chất, sau 60 phút thủy phân ở $\mathrm{pH} 6,5,55^{\circ} \mathrm{C}$ thu được $7,88 \mathrm{mg} / \mathrm{g}$ amino acid tổng trong dịch protein, thấp hơn gần 8 lần so với mẫu dịch đạm chúng tôi thủy phân được từ trùn quế [31]. Kechaou và cộng sự (2009) thực hiện thủy phân mực và cá mòi bằng enzyme Alcalase cung cấp bởi công ty Novozymes với tỉ lệ $0,1 \%$ so với cơ chất, đồng nhất mẫu với nước cất ở tỉ lệ $1: 1, \mathrm{pH} 8,0,50^{\circ} \mathrm{C}, 300 \mathrm{rpm}$ trong 24 giờ cho hàm lượng amino acid tổng rất cao $3,508 \mathrm{mmol} / \mathrm{mg}$ (mực) và $2,751 \mathrm{mmol} / \mathrm{mg}$ (cá mòi) nhưng không thu nhận được histidine - amino acid thiết yếu cho heo con [32].

Với thành phần và hàm lượng amino acid thiết yếu và không thiết yếu có trong mẫu bột đạm, chúng tôi nhận thấy rằng chế phẩm bột đạm này hoàn toàn phù hợp và có triển vọng trong việc sử dụng làm nguồn thức ăn bổ sung cho heo, đặc biệt là heo con giai đoạn đang cai sữa.

\subsection{Bước đầu thử nghiệm hiệu quả của bột thịt trùn quế trên đàn heo con lai sau cai sữa}

Đàn heo con sau cai sữa khoẻ mạnh, không phân biệt giới tính, có trọng lượng trung bình khoảng 7,0 $\mathrm{kg} / \mathrm{con}$ được chia thành 4 lô thí nghiệm. Mỗi lô được phân thành 2 ngăn nhỏ, mỗi ngăn nhỏ có 6 cá thể heo con. Heo con, chuồng trại và thức ăn nền được cung cấp bởi trại chăn nuôi Vĩnh Khánh thuộc Công ty Cổ phần xuất nhập khẩu nông sản thực phẩm An Giang.

Đàn heo được cân trọng lượng khi nhập chuồng và sau mỗi tuần thực nghiệm. Trọng lượng của đàn heo được ghi nhận trong bảng 1 . Từ đó chúng tôi xác định được tốc độ tăng trưởng của mỗi đàn heo so với khi nhập chuồng (bảng 2). Theo kết quả ghi nhận được, đàn heo được cho ăn với khẩu phần có bổ sung $2 \%$ bột thịt trùn quế có sự tăng trưởng nhỉnh hơn các đàn heo khác. Chúng tôi tiến hành phân tích kết quả bằng chương trình phân tích ANOVA 2 yếu tố có lặp (GraphPad Prism 8), kết quả phân tích cho thấy có sự khác biệt giữa lô thí nghiệm $\mathrm{C}$ so với các lô thí nghiệm khác. Mặc dù sự khác biệt này không quá lớn nhưng có ý nghĩa rất cao trong thực nghiệm của chúng tôi.

Bảng 1: Khối lượng đàn heo (12 cá thể/đàn) sau mỗi tuần nuôi thực nghiệm (đvt: $\mathrm{kg}$ )

\begin{tabular}{|c|c|c|c|c|c|}
\hline & Tuần 0 & Tuần 1 & Tuần 2 & Tuần 3 & Tuần 4 \\
\hline Lô A & $82,66 \pm 4,06$ & $96,96 \pm 3,90$ & $118,35 \pm 3,23$ & $146,59 \pm 2,12$ & $176,30 \pm 5,75$ \\
\hline Lô B & $86,70 \pm 2,47$ & $102,23 \pm 0,61$ & $129,47 \pm 0,92$ & $156,78 \pm 1,21$ & $187,55 \pm 6,90$ \\
\hline Lô C & $86,03 \pm 3,61$ & $104,03 \pm 1,27$ & $137,23 \pm 0,14$ & $170,84 \pm 0,54$ & $201,04 \pm 4,52$ \\
\hline Lô D & $83,92 \pm 4,10$ & $99,39 \pm 5,32$ & $125,26 \pm 3,88$ & $157,47 \pm 1,80$ & $185,11 \pm 2,40$ \\
\hline
\end{tabular}

Bảng 2: Tốc độ tăng trưởng của mỗi đàn heo (đvt: \%)

\begin{tabular}{|c|c|c|c|c|}
\hline & Tuần 1 & Tuần 2 & Tuần 3 & Tuần 4 \\
\hline Lô A & $17,36 \pm 3,36$ & $43,28 \pm 3,29$ & $77,69 \pm 10,58$ & $113,78 \pm 15,87$ \\
\hline Lồ B & $17,99 \pm 4,11$ & $49,42 \pm 5,24$ & $80,93 \pm 6,02$ & $116,53 \pm 12,99$ \\
\hline Lô C & $21,03 \pm 3,93$ & $59,71 \pm 6,77$ & $98,82 \pm 8,66^{*}$ & $133,84 \pm 6,79^{* *}$ \\
\hline Lố D & $18,43 \pm 1,39$ & $49,66 \pm 12,21$ & $87,98 \pm 10,21$ & $120,87 \pm 8,83$ \\
\hline
\end{tabular}

Phân tích ANOVA 2 yếu tố có lặp với $\alpha=0,05$ cho thấy không có sự khác biệt giữa các lô thí nghiệm trong 2 tuần đầu, từ tuần thứ 3 sự tăng trọng của đàn heo trong lô $\mathrm{C}$ có sự khác biệt với các lô còn lại ( ${ }^{*} P=0,0451<0,05$, $P=0,0472<0,05$ ).

Heo con sau cai sữa cần được cung cấp đầy đủ dinh dưỡng với thành amino acid cân đối. Tuy nhiên việc cung cấp khẩu phần ăn quá nhiều đạm sẽ khiến heo con đi phân lỏng do hệ thống lông ruột chưa thật sự phát triển [33]. Việc đi phân lỏng có tác động xấu đến sự tăng trưởng của heo đặc biệt là giai đoạn sau cai sữa. Đây cũng là giai đoạn quyết định đến sự tăng trưởng vượt bật của heo sau này [34]. Lô $\mathrm{D}$ được cho ăn với khẩu phần ăn có $3 \%$ bột thịt trùn quế cao hơn lô $\mathrm{C}$ nhưng tốc độ tăng trưởng của lô $\mathrm{D}$ thấp hơn. Trong quá trình thực nghiệm, chúng tôi ghi nhận những heo con ở lô $\mathrm{D}$ có tỷ lệ đi phân lỏng cao hơn các lô thực nghiệm khác (bảng 3 ). Đăc biệt tỷ lệ heo con đi phân lỏng ở lô $\mathrm{C}$ thấp chỉ bằng $1 \frac{1}{2}$ so với lô $\mathrm{D}$. Tuy nhiên việc đi phân lỏng của đàn heo chỉ được ghi nhận nhiều vào 2 tuần đầu. Hiện tượng này không 
còn được ghi nhận ở tuần thứ 4 . Xét về khía cạnh thống kê, sự tăng trọng của đàn heo trong lô $\mathrm{C}$ không quá khác biệt so với các lô còn lại. Tuy nhiên, trong ngành chăn nuôi tỷ lệ khác biệt này thật sự có ý nghĩa.

Bảng 3: Tỷ lệ tiêu cháy ở các đàn heo trong 3 tuần đầu được nuôi với chế độ bổ sung bột đạm

\begin{tabular}{|c|c|c|c|}
\hline $\begin{array}{c}\text { Lô thực } \\
\text { nghiệm }\end{array}$ & Tuẩn 1 & Tuần 2 & Tuà̀n 3 \\
\hline $\mathrm{A}$ & $12,70 \%$ & $15,86 \%$ & $3,78 \%$ \\
\hline $\mathrm{B}$ & $10,32 \%$ & $14,29 \%$ & $3,38 \%$ \\
\hline $\mathrm{C}$ & $8,94 \%$ & $10,08 \%$ & $1,59 \%$ \\
\hline $\mathrm{D}$ & $17,06 \%$ & $21,83 \%$ & $5,97 \%$ \\
\hline
\end{tabular}

Bảng 4: Số lượng bạch cẩu trung bình ờ mỡi cá thẻ̉ lợn trong các lô thực nghiệm

\begin{tabular}{|c|c|}
\hline $\begin{array}{c}\text { Lô thực } \\
\text { nghiệm }\end{array}$ & $\begin{array}{c}\text { Số lượng bạch cầu } \\
\left(\mathrm{nghin} / \mathrm{mm}^{3}\right)\end{array}$ \\
\hline $\mathrm{A}$ & $21,75 \pm 1,21$ \\
\hline $\mathrm{B}$ & $19,45 \pm 2,64$ \\
\hline C & $18,75 \pm 3,78$ \\
\hline $\mathrm{D}$ & $22,05 \pm 2,76$ \\
\hline
\end{tabular}

Phân tich ANOVA 1 yếu tố vời $\alpha=0,05$ cho thály khỏng có sự khác biệt giưta các lô thực nghię̂m

Việc bổ sung 1 thành phần nào đó vào khẩu phần ăn của heo cũng sẽ gây tác động lên hệ tuần hoàn và miễn dịch của heo. Thông số cơ bản nhất để đánh giá tác động của thức ăn bổ sung lên sinh lý là hàm lượng bạch cầu trong máu heo sau khi ăn thức ăn bổ sung [35]. Sau 4 tuần thực nghiệm, chúng tôi tiến hành lấy máu sau tai của heo để xác định số lượng bạch cầu, máu được đựng trong ống tráng heparin, bảo quản lạnh ở $4^{\circ} \mathrm{C}$. Số lượng bạch cầu trung bình ở các cá thể heo con đều ở giá trị sinh lý bình thường, số lượng này phù hợp với các báo cáo trước đây [36]. Kết quả cho thấy không có sự khác biệt rõ rệt về số lượng bạch cầu ở các lô heo thí nghiệm (bảng 4). Việc cho heo con ăn thêm bột đạm từ thịt trùn quế không gây tác động xấu lên hoạt động sinh lý cũng như không gây kích ứng miễn dịch ở bầy heo con.

\section{KẾT LUẬN}

Trùn quế là nguồn nguyên liệu dồi dào, hàm lượng đạm cao và hữu ích. Việc nghiên cứu chế biến thịt trùn quế thành các dạng sản phẩm thương mại có giá trị cao luôn là nhu cầu cấp thiết. Trong nghiên cứu của mình, chúng tôi đã thành công trong việc sản xuất được bột đạm từ thịt trùn quế bằng công nghệ thuỷ phân sinh học và kỹ thuật sấy phun. Sản phẩm tạo ra có giá trị dinh dưỡng và giá trị cảm quan phù hợp với việc bổ sung cho đàn heo con sau cai sữa. Điều này đã được chứng minh thông qua việc thực nghiệm trên đàn heo con sau cai sữa của trại chăn nuôi Vĩnh Khánh thuộc Công ty Cổ phần xuất nhập khẩu nông sản thực phẩm An Giang. Đàn heo có ăn bột đạm bổ sung đã có sự tăng trưởng đáng ghi nhận và có sức khoẻ ổn định sau giai đoạn thực nghiệm. Chúng tôi sẽ tiếp tục thực hiện các nghiên cứu trên nhiều đối tượng khác để có thể thương mại hoá sản phẩm bột đạm từ thịt trùn quế.

LỜI CẢM ON: Chúng tôi chân thành cảm ơn Trường Đại học Công nghiệp Tp. Hồ Chí Minh đã cấp kinh phí để thực hiện đề tài nghiên cứu có mã số 194.TP02. Chúng tôi xin chân thành cảm ơn Ban giám đốc Công ty Cổ phần xuất nhập khẩu nông sản thực phẩm An Giang đã tạo điều kiện thuận lợi cho chúng tôi thực hiện nghiên cứu này tại trại chăn nuôi Vĩnh Khánh thuộc Công ty.

\section{TÀI LIỆU THAM KHẢO}

1. Tan, B., et al., Dietary L-arginine supplementation enhances the immune status in early-weaned piglets. Amino Acids, 2009. 37(2): p. 323-31.

2. $\quad$ Kim SW, W.G., Baker DH., Ideal protein and amino acid requirements by gestating and lactating sows. Pig News and Information, 2005. 26(4): p. 89N-99N.

3. Mateo, R.D., et al., Effects of dietary arginine supplementation during gestation and lactation on the performance of lactating primiparous sows and nursing piglets. J Anim Sci, 2008. 86(4): p. 827-35.

4. Jobgen, W.S., et al., Regulatory role for the arginine-nitric oxide pathway in metabolism of energy substrates. J Nutr Biochem, 2006. 17(9): p. 571-88. 
5. $\quad \mathrm{Wu}, \mathrm{G} .$, Functional amino acids in growth, reproduction, and health. Adv Nutr, 2010. 1(1): p. 31 7.

6. $\quad$ Li, P., et al., Amino acids and immune function. Br J Nutr, 2007. 98(2): p. 237-52.

7. $\mathrm{Wu}, \mathrm{G}$. , et al., Impacts of amino acid nutrition on pregnancy outcome in pigs: mechanisms and implications for swine production. J Anim Sci, 2010. 88(13 Suppl): p. E195-204.

8. Anthony, J.C., et al., Orally administered leucine stimulates protein synthesis in skeletal muscle of postabsorptive rats in association with increased eIF4F formation. J Nutr, 2000. 130(2): p. 139-45.

9. Curry J.P., S.O., The feeding ecology of earthworms - a review. Pedobiologia, 2007. 50: p. 463477.

10. Sogbesan AO, U.A., Nutritional values of some non-conventional animal protein feedstuffs used as fishmeal supplement in aquaculture practices in Nigeria. Turk J Fish Aquat Sci, 2008. 8: p. 159164.

11. Edwards, C.A.a.L., J., Biology of Earthworms. Springer, 1972.

12. Xiang C, Z.P., Pan G, Qiu D, Chu Q., Changes in diversity, protein content, and amino acid composition of earthworms from a paddy soil under different long-term fertilizations in the Tai Lake Region, China. Acta Ecol Sin, 2006. 26(6): p. 1667-1674.

13. Kangmin Li, P.L.a.H.L., Earthworms helping economy, improving ecology and protecting health. International Journal of Global Environmental Issues, 2010. 10(1): p. 354-365.

14. Mombach PI, P.D., Adorian TJ, Uczay J, Lazzari R., Farinha de minhoca em dietas para juvenis de jundia'. Pesq Agropec Trop, 2014. 44(2): p. 151-157.

15. Kristinsson, H.G. and B.A. Rasco, Fish protein hydrolysates: production, biochemical, and functional properties. Crit Rev Food Sci Nutr, 2000. 40(1): p. 43-81.

16. Shahidi F, A.J., Jeon YJ., Food applications of chitin and chitosans. Trends Food Sci Technol, 1999. 10: p. 37-51.

17. Maldonado, J., et al., Special formulas in infant nutrition: a review. Early Hum Dev, 1998. 53 Suppl: p. S23-32.

18. Castro HC, A.P., Geraldo RB, Martins RCA, Santos R, Loureiro NI, Cabral LM, Rodrigues CR., Looking at the proteases from a simple perspective. J Mol Recognit, 2011. 24: p. 165-181.

19. Duarte JG, S.L., Freire DMG, Cammarota MC, Gutarra MLE., Enzymatic hydrolysis and anaerobic biological treatment of fish industry effluent: evaluation of the mesophilic and thermophilic conditions. Renew Energy, 2015. 83: p. 455-462.

20. Lin, Q., S. Xiao-li, and X. Xian-lin, Study on Enzymatic Technology of Earthworm Peptides Produced by Alcalase. 2010.

21. Silva, C.R.d., A.B. Delatorre, and M.L.L. Martins, Effect of the culture conditions on the production of an extracellular protease by thermophilic Bacillus sp and some properties of the enzymatic activity. Brazilian Journal of Microbiology, 2007. 38: p. 253-258.

22. Kamnerdpetch, C., et al., An improvement of potato pulp protein hydrolyzation process by the combination of protease enzyme systems. Enzyme and Microbial Technology, 2007. 40(4): p. 508514.

23. De La Roza, C., et al., Stirring and Mixing Effects at Different Cider Fermentation Scales. Food and Bioproducts Processing, 2002. 80(2): p. 129-134.

24. Wang, Z.-P., et al., Efficient Conversion of Cane Molasses Towards High-Purity Isomaltulose and Cellular Lipid Using an Engineered Yarrowia lipolytica Strain in Fed-Batch Fermentation. Molecules (Basel, Switzerland), 2019. 24(7): p. 1228.

25. Nirmal, N.P. and R.S. Laxman, Enhanced Thermostability of a Fungal Alkaline Protease by Different Additives. Enzyme Research, 2014. 2014: p. 109303.

26. von Berg, A., et al., Allergic manifestation 15 years after early intervention with hydrolyzed formulas--the GINI Study. Allergy, 2016. 71(2): p. 210-9.

27. Rawlings, N.D., et al., MEROPS: the peptidase database. Nucleic Acids Res, 2008. 36(Database issue): p. D320-5.

28. Rawlings, N.D., A.J. Barrett, and R. Finn, Twenty years of the MEROPS database of proteolytic enzymes, their substrates and inhibitors. Nucleic Acids Res, 2016. 44(D1): p. D343-50. 
29. Flynn, A., The role of dietary calcium in bone health. Proc Nutr Soc, 2003. 62(4): p. 851-8.

30. Hương, N.T.M., Thành phần dinh dữong của các sản phẩm thuỷ phân tù̀ đầu và xương cá chẽm (Lates calcarifer) bằng enzyme lavourzyme,. Tạp chí Khoa học Trường Đại học Cần Thơ., 2014. 1: p. 49-53.

31. Liaset, B., K. Julshamn, and M. Espe, Chemical composition and theoretical nutritional evaluation of the produced fractions from enzymic hydrolysis of salmon frames with Protamex ${ }^{\mathrm{TM}}$. Process Biochemistry, 2003. 38(12): p. 1747-1759.

32. Kechaou, E.S., et al., Enzymatic hydrolysis of cuttlefish (Sepia officinalis) and sardine (Sardina pilchardus) viscera using commercial proteases: effects on lipid distribution and amino acid composition. J Biosci Bioeng, 2009. 107(2): p. 158-64.

33. Ekstrom, G.M. and B.R. Westrom, Cathepsin B and D activities in intestinal mucosa during postnatal development in pigs. Relation to intestinal uptake and transmission of macromolecules. Biol Neonate, 1991. 59(5): p. 314-21.

34. Wu, Y., et al., Effects of protein sources and levels in antibiotic-free diets on diarrhea, intestinal morphology, and expression of tight junctions in weaned piglets. Anim Nutr, 2015. 1(3): p. 170176.

35. Wang, Y., et al., Advances in low-protein diets for swine. Journal of animal science and biotechnology, 2018. 9: p. 60-60.

36. Ježek, J., et al., The influence of age, farm, and physiological status on pig hematological profiles. Journal of Swine Health and Production, 2018. 26(2): p. 72-78. 